\title{
Çocuklarda Post-Operatif Dönemde Non-Farmakolojik Ağrı Giderme Yöntemi Olarak Müziğin Kullanılması: Sistematik Derleme
}

\author{
Merve GÜMÜŞ* $\quad$ Didem YÜKSEL ** Recep KARA*** \\ Figen YARDIMCI**** Selmin SENOL***** Hatice BAL YILMAZ******
}

Öz

Amaç: Bu sistematik derleme, çocuklarda post-operatif dönemde non-farmakolojik ağrı giderme yöntemi olarak müziğin etkisini incelemek amacıyla yapılmıştır. Yöntem: Çocuklarda post-operatif dönemde kullanılan müziğin ağrıya etkisini belirlemek için Pubmed, Proquest, Science Direct ve EBSCOhost, ClinicalKey, Ovid elektronik veri tabanları beş anahtar sözcük kullanılarak taranmıştır. Tarama sonucunda araştırma kapsamına beş çalışma dahil edilmiştir. Bulgular: Değerlendirmeye alınan çalışmaların üçünde ağrının kontrol gruplarına göre anlamlı derecede azaldığ 1 , bir çalışmada opioid analjezik kullanım ihtiyacının azaldığı ve bir çalışmada ise iki grubun da ağrısının azaldığ 1 fakat istatistiksel açıdan anlamlı olmadığı saptanmıştır. Çalışmalarda kayıtlı ve canlı müzik terapi yönteminin 3-19 yaş grubundaki çocuklarda cerrahi sonrası non-farmakolojik yöntem olarak kullanıldığı ve hissedilen ağrıyı azaltmada etkili olduğu görülmüştür. Sonuç: Çalışmalarda kayıtlı ve canlı müzik terapi yönteminin çocuklarda cerrahi sonrası non-farmakolojik yöntem olarak kullanıldı̆̆ı ve hissedilen ağrıyı azaltmada etkili olduğu görülmüştür. Çocuklarda cerrahi sonrası ağrıyı gidermek için müzik terapi yönteminin non-farmakolojik bir hemşirelik girişimi olarak kullanılmasının yaygınlaştırılması ve bu amaçla eğitimlerin yapılması önerilmektedir.

Anahtar Sözcükler: Postoperatif Ağrı, Çocuk, Müzik, Cerrahi, Hemşirelik.

\section{Abstract
Using Music as a Non-pharmacological Pain Relief Method in Post-operative Period in Children: A Systematic Review}

Objective: This systematic review was performed to determine the effects of music used as a method of relieving pain in the post-operative period in children. Method: In order to determine the effect of music used in post-operative period on pain in children, Pubmed, Proquest, Science Direct and EBSCOhost, ClinicalKey, Ovid electronic databases were scanned with five keywords. As a result of the study, five studies were included in the study. Results: In three of the studies evaluated, the pain was significantly decreased compared to the control groups, in one study, the need for opioid analgesia decreased and in one study the pain of the two groups decreased but it was not statistically significant. In the studies, it was found that recorded and live music therapy method was used as a non-pharmacological method after surgery in children between the ages of 3-19 and it was effective in reducing pain. Conclusion: It was found that recorded and live music therapy method was used as a non-pharmacological method in children after surgery and decreased the pain. In order to relieve the pain after the surgery, it is recommended that the use of the music therapy method as a nursing initiative should be made widespread and training should be carried out for this purpose.

Key Words: Postoperative Pain, Children, Music, Surgery, Nursing

\section{Geliş tarihi: 17.10.2019 Kabul tarihi: 08.09.2020}

$\mathrm{U}$ luslararası Ağrı Araştırmaları Derneği Taksonomi Komitesi ağrıyı, "Vücudun belirli bir bölgesinden kaynaklanan, doku harabiyetine bağlı olan/olmayan bireyin geçmişteki deneyimleriyle ilgili istenmedik emosyonel bir duyum ya da davranış şekli" olarak tanımlamıştır (1). Çocuklara uygulanan tıbbi girișim onlar için en kötü deneyimler arasındadır ve çocuklar girişim öncesi, sırası veya sonrasında korku, endişe ve ağrı yaşayabilirler (2,3). Postoperatif ağrı, multidisipliner bir yaklaşım gerektiren karmaşık bir süreçtir ve hastaların \%80’i ciddi şiddette ağrı tanılamaktadır $(4,5)$. Postoperatif dönemde çocukların yaşadıkları ağrı, çocuklarla çalışan sağlık profesyonelleri için önemli bir sorundur (5-8). Birçok çalışma çocuklarda post-operatif dönemde gelişen ağriyı yönetmenin yetersiz olduğunu göstermektedir $(9,10)$. Lee ve Jo (2014) bu yetersizliğin nedenini, ağrıyı tanılamakta yaşanılan zorluklar ve opioid analjeziklerin çocuklar üzerindeki yan etkilerinden kaynaklı olduğunu savunmuştur (11).

Post-operatif dönemde ağrının uygun tedavisi ile hastanede kalış süresinin azalması, bakım maliyetlerinin düşmesi ve hasta memnuniyetinin artması mümkündür. Post-operatif ağrının yara yeri iyileşmesini geciktirdiği ve negatif ağrı deneyiminin hastanın ağrı algısını etkileyerek kronik bir ağrıya dönüşebileceğini gösteren çalışmalar mevcuttur (12-14). Uzun yıllar boyunca çocukların postoperatif ağrı yönetimini iyileştirme çabaları artmakta olmasına rağmen halen post-operatif dönemde ağrı çeken önemli sayıda çocuk bulunmaktadır (15-18).

Non-farmolojik yöntemler ağrı kontrolünde yaygın olarak kullanılmaktadır. Müzik non-farmakolojik bir ağrı giderme yöntemidir ve kullanılan iki çeşit müzik türü vardır; Canlı müzik terapi ve kayıtlı müzik terapi. Müzik dinlemek terapi, düşük maliyetli, kolay bulunabilen ve güvenli bir ağrı giderme yöntemidir. Ağrılı işlemler sırasında destek ya da alternatif olarak müzik dinlemenin ağrıyı ve analzejik ihtiyacını azalttı̆̆ını gösteren çalışmalar mevcuttur $(19,20)$. Müzik non-farmokolojik ağrı giderme yöntemi olarak yaygın bir şekilde kullanılmaktadır (21).

$\mathrm{Bu}$ sistematik derleme, müziğin ağrı giderilmesi üzerine evrensel etkilerini vurgulamak ve pediatrik hastalarda postoperatif dönemde müzik terapisinin faydalarını bilimsel olarak kanıtlamak için, uluslararası iş birliğine duyulan ihtiyaçlar konusunda bir tartışma başlatmayı hedeflemektedir.

*Araş. Gör. Ege Üniversitesi Hemşirelik Fakültesi Çocuk Sağlığı ve Hastalıkları Hemşireliği Anabilim Dalı, 35100, Bornova/İzmir/Türkiye. Orcid No: 00000001-8648-594X **Araş. Gör. Ufuk Üniversitesi Hemşirelik Yüksek Okulu, 06520, Balgat/Ankara/Türkiye. E-posta: didem.yuksel@ufuk.edu.tr Orcid No: 0000-0003-2120-7679 ***Araş. Gör. Muğla Sıtkı Kocaman Üniversitesi Fethiye Sağlık Bilimleri Fakültesi Hemşirelik Bölümü Çocuk Sağlığı ve Hastalıkları Hemşireliği Anabilim Dalı, 4800, Menteşe/Muğla/Türkiye. Orcid No: 0000-0001-5742-9842 ****Doç. Dr. Ege Üniversitesi Hemşirelik Fakültesi Çocuk Sağlığı ve Hastalıkları Hemşireliği Anabilim Dalı, 35100, Bornova/Türkiye. Orcid No: 0000-0002-1550-985X *****Doç. Dr. Ege Üniversitesi Hemşirelik Fakültesi Çocuk Sağlığı ve Hastalıkları Hemşireliği Anabilim Dalı, 35100, Bornova/Türkiye. Orcid No: 0000-0003-4716-3512 ******Prof. Dr. Ege Üniversitesi Hemşirelik Fakültesi Çocuk Sağlığı ve Hastalıkları Hemşireliği Anabilim Dalı, 35100, Bornova/Türkiye. Orcid No: 0000-0001-8015-6379 


\section{Araştırmanın Amacı}

$\mathrm{Bu}$ araştırmanın amacı; çocuklarda post-operatif dönemde müziğin ağrı yönetimine etkisi ile ilgili olan yayımlanmış çalışmaların gözden geçirilmesi ve bu çalışmalardan elde edilen verilerin sistematik biçimde incelenmesidir.

\section{Araştırmanın Soruları}

- Çocuklarda müzik dinletisinin post-operatif dönemde ağrı üzerine etkisi var mı?

\section{Yöntem}

Yazarlar tarafından, 2009 ile 2019 tarihleri arasında yayınlanmış 572 çalışma incelenmiştir. Pubmed, Proquest, Science Direct ve EBSCOhost, ClinicalKey, Ovid elektronik veri tabanları "postoperative pain”, “children”, "music”, "surgery” ve “nursing” anahtar kelimeleri kullanılarak taranmıştır. Elektronik arama ile saptanan ilgili tüm yazıların başlık ve özetleri, araştırmacılar tarafından bağımsız olarak gözden geçirilmiştir. Eğer başlık ya da özet açık değilse, çalışmanın dahil olma kriterlerine uyup uymadığının araştırılması için çalışmanın tam metni incelenmiştir. Elde edilen çalışmalardan yalnızca randomize kontrollü çalışma (RKÇ) incelemeye dahil edilmiştir. Çalışmada incelenen makale sayısı 572 olmasına rağmen, dahil edilme kriterlerine uyan beş makale çalışma kapsamına alınmıştır. Araştırmaya dahil edilme kriteri olarak; RKÇ olması, çocuk hastalarda postoperatif ağrıya yönelik müzik terapi uygulanmış olması, yayın dilinin Türkçe ya da İngilizce olması, 2009 ile 2019 tarihleri arasında yayınlanmış olması, tam metnine ulaşılabilmesi belirlenmiştir. Çalışmaya alınan araştırmalarda çocuklar 3-19 yaşları arasındadır. Araştırma türü olarak in-vitro çalışmalar, olgu sunumları, devam eden çalışmalar, meta analizler, sistematik derlemeler ve kontrollü deneysel çalışmalar kapsam dışı bırakılmıştır. Araştırmacılar arasındaki güvenirliği sağlamak için beşinci bir araştırmacı tarafından tüm sayının \%10’u kadar olan 57 veri rastgele bir şekilde seçilip dâhil edilme kriterleri açısından incelenmiş ve değerlendirmeler arasında \%100'lük bir uyum olduğu tespit edilmiştir. Yöntem şekil 1'de özetlenmiştir.

Anahtar kelimelerle \{“postoperative pain”, “children”, “music”, "surgery” ve "nursing”\} Pubmed, Proquest, Science Direct ve EBSCOhost, ClinicalKey, Ovid elektronik veri tabanları tarandı.

Toplam 572 çalışmaya ulaşıldı.

Çalışmalar listelendi ve dahil edilme kriterlerine göre değerlendirildi

Üç çalışma yayın dilinin Türkçe ya da İngilizce olma koşulunu sağlamadığından kapsam dışı bırakıldı.

Kriterlere uymayan 542 çalışma kapsam dışı bırakıldı.

20 çalışma randomize kontrollü olma koşulunu sağlamadığı için iki çalışma tam metne ulaşılamadı̆̆ için kapsam dışı bırakıldı.

Çalışma kapsamına alınan toplam beş çalışma; karşılaştırma, sınırlılık ve sonuçlar açısından değerlendirildi.

\section{Şekil 1. İşlem basamakları akış şeması}

\section{Bulgular}

Sistematik derlemeye dahil edilen beş çalışmanın 1'i Türkiye'de, 2'si Amerika Birleşik Devletleri'nde, 1'i İtalya'da ve 1'i İsviçre'de yürütülmüştür. İncelenen çalışmalarda müzik terapi yönteminin 3-19 yaş grubundaki çocuklarda cerrahi sonrası nonfarmakolojik yöntem olarak kullanıldığı bulunmuştur. Müzik tercihine bakıldığında 1'i canlı müzik, 4'ü kayıtlı müzik tercih etmiştir. Çalışmalarda kullanılan müziklerin dinletilme sürelerine bakıldığında ikisinde 30 dakika (24,29), birinde üç kez 30'ar dakika (25), birinde 20 dakika (26) ve birinde ise 45 dakika (23) olarak belirlenmiştir. Ayrıca müzik terapinin bir çalışmada ayılma ünitesinde bir çalışmada postoperatif bakım ünitesinde, diğer üç çalışmada cerrahi servislerinde yürütüldüğü bulunmuştur. 
Tablo 1. Değerlendirilme Kapsamına Alınan Çalışmalar

\begin{tabular}{|c|c|c|c|}
\hline Çalışma adı / Yılı/ Yazarları & Örneklem sayısı / Yöntem & Sonuçlar & Sinırlılık \\
\hline $\begin{array}{l}\text { School-aged children's experiences } \\
\text { of postoperative music medicine on } \\
\text { pain, distress, and anxiety / } 2009 \text { / } \\
\text { Stefan Nilsson, Eva Kokinsky, } \\
\text { Ulrica Nilsson, Birgitta Sidenvall } \\
\text { And } \\
\text { Karin Enskar }\end{array}$ & $\begin{array}{l}\text { 7-16 yaş arası } 80 \text { hasta ile } \\
\text { çalışma yapılmıştır. } \\
\text { Müzik ve kontrol grubu olmak } \\
\text { üzere iki grup } \\
\text { karşılaştırılmıştır. } \\
\text { Çocukların ağrısı 'Coloured } \\
\text { Analogue Scale' ile } \\
\text { değerlendirilmiştir. }\end{array}$ & $\begin{array}{l}\text { Minör cerrahi sonrası müzik } \\
\text { gurubunda morfin ihtiyacının } \\
\text { anlamlı derecede azaldığı } \\
\text { fakat anksiyete ve ağrıya } \\
\text { etkisi olmadığı bulunmuştur. } \\
\text { Çocukların müziği } \\
\text { sakinleştirici ve rahatlatıcı } \\
\text { olarak değerlendirdiği } \\
\text { belirtilmiştir. }\end{array}$ & $\begin{array}{l}\text { Çalışmanın kör } \\
\text { yapılamamış } \\
\text { olması sınırlılık } \\
\text { olarak } \\
\text { bildirilmiştir. }\end{array}$ \\
\hline $\begin{array}{l}\text { Music benefits on postoperative } \\
\text { distress and pain in pediatric day } \\
\text { care surgery /2014/ } \\
\text { Valeria Calcaterra, Selene Ostuni, } \\
\text { Irene Bonomelli, Simonetta } \\
\text { Mencherini, Marco Brunero, Elisa } \\
\text { Zambaiti, Savina } \\
\text { Mannarino, Daniela Larizza, } \\
\text { Riccardo Albertini, Carmine Tinelli } \\
\text { and } \\
\text { Gloria Pelizzo }\end{array}$ & $\begin{array}{l}\text { 3-14 yaş arası günübirlik } \\
\text { cerrahi operasyon planlanan } \\
42 \text { çocuk araştırmaya dahil } \\
\text { edilmiştir. Çocuklar müzik } \\
\text { grubu ve kontrol grubu olmak } \\
\text { üzere iki gruba ayrılmışlar. } \\
\text { Müzik grubuna uyanma } \\
\text { ünitesinde klasik müzik } \\
\text { dinletilmiştir ( } 20 \text { dakika). } \\
\text { Kontrol grubu standart bakım } \\
\text { almıştır. } \\
\text { Çocukların ağrısı 'Face, Legs, } \\
\text { Activity, Cry, Consolabity } \\
\text { (FLACC) Pain Scale' ile } \\
\text { değerlendirilmiştir. }\end{array}$ & $\begin{array}{l}\text { Müzik grubunda uyanmanın } \\
\text { daha yavaş olduğu, kan } \\
\text { basıncının ve kan glukoz } \\
\text { değerinin daha düşük olduğu } \\
\text { bulunmuştur. Ağrı puanları, } \\
\text { kalp atım hızı ve serum } \\
\text { kortizol düzeyleri açısından } \\
\text { iki grup arasında anlamlı } \\
\text { farklılık bulunmamıştır. }\end{array}$ & $\begin{array}{l}\text { Araştırmaya } \\
\text { katılan çocukların } \\
\text { cinsiyetleri } \\
\text { açısından } \\
\text { homojenlik } \\
\text { olmaması } \\
\text { sinırlılik olarak } \\
\text { bildirilmiştir. }\end{array}$ \\
\hline $\begin{array}{l}\text { The effect of audio therapy to treat } \\
\text { postoperative pain in children } \\
\text { undergoing major surgery: a } \\
\text { randomized controlled trial / 2015/ } \\
\text { B. S. Sunitha Suresh, Gildasio S. De } \\
\text { Oliveira Jr. and Santhanam Suresh }\end{array}$ & $\begin{array}{l}\text { 6-18 yaş arasında } 60 \text { hasta } \\
\text { alınması planlanıp } 56 \text { hasta ile } \\
\text { çalışma bitirilmiştir. / } \\
\text { Sesli kitap, müzik ve sessizlik } \\
\text { olarak } 3 \text { grup } \\
\text { karşılaştırılmıştır. } \\
\text { Çocukların ağrısı 'The Faces } \\
\text { Pain Scale’ ile } \\
\text { değerlendirilmiştir. }\end{array}$ & $\begin{array}{l}\text { Major elektif cerrahi sonrası } \\
\text { ağrı skorlarının hem müzik } \\
\text { grubunda hem de sesli kitap } \\
\text { grubunda azaldığı } \\
\text { bulunmuştur. }\end{array}$ & $\begin{array}{l}\text { Çocukların } \\
\text { ağrısını } \\
\text { etkileyebilecek } \\
\text { kişisel özelliklerin } \\
\text { kontrol } \\
\text { edilememesi, } \\
\text { hasta ve } \\
\text { gözlemcilerin } \\
\text { araştırmanın } \\
\text { doğası gereği } \\
\text { körleştirilememesi } \\
\text { olarak } \\
\text { bildirilmiştir. }\end{array}$ \\
\hline $\begin{array}{l}\text { Relaxation Training and } \\
\text { Postoperative Music } \\
\text { Therapy for Adolescents } \\
\text { Undergoing Spinal Fusion Surgery } \\
\text { / } 2016 \text { / Kirsten Nelson, Mary } \\
\text { Adamek, and Charmaine Kleiber }\end{array}$ & $\begin{array}{l}\text { Spinal füzyon operasyonu } \\
\text { öncesi müzik terapi eğitimi } \\
\text { alıp post-operatif dönemde } \\
\text { müzik terapi alan adölesanlar } \\
\text { ile pre-operatif eğitim } \\
\text { almadan post-operatif } \\
\text { dönemde müzik terapi alanlar } \\
\text { olmak üzere iki grup } \\
\text { karş1laştırılmıştır. Araştırma } \\
\text { 10-19 yaş arası } 44 \text { adölesan ile } \\
\text { gerçekleştirilmiştir. } \\
\text { Çocukların ağrısı 'Numeric } \\
\text { Rating Scale (NRS)' ile } \\
\text { değerlendirilmiştir. }\end{array}$ & $\begin{array}{l}\text { Her iki grupta da anksiyete ve } \\
\text { ağrı puanlarında azalma } \\
\text { belirtilmiştir. }\end{array}$ & $\begin{array}{l}\text { Hasta kontrollü } \\
\text { analjezik alımı } \\
\text { nedeniyle veri } \\
\text { kaybı olması, } \\
\text { örneklem } \\
\text { sayısının az } \\
\text { olması ve } \\
\text { çalışmada yer alan } \\
\text { hemşirenin } \\
\text { yoğunluğu } \\
\text { araştırmanın } \\
\text { sınırlılıkları } \\
\text { olarak } \\
\text { bildirilmiştir. }\end{array}$ \\
\hline $\begin{array}{l}\text { Ortopedi servisinde yatan çocuk } \\
\text { hastalarda ameliyat sonrası ağrı } \\
\text { yönetiminde müziğin etkisinin } \\
\text { incelenmesi/ 2019/ Serap Sayar ve }\end{array}$ & $\begin{array}{l}\text { 7-12 yaş arası ortopedik } \\
\text { cerrahi operasyonu sonrası } 60 \\
\text { çocuk hasta araştırmaya dahil } \\
\text { edilmiştir. Girişim grubundaki }\end{array}$ & $\begin{array}{l}\text { Müzik dinletilen grubun } \\
\text { ameliyat sonrası ilk altı } \\
\text { saatteki ağrı puanı } \\
\text { ortalamaları kontrol grubuna }\end{array}$ & $\begin{array}{l}\text { Araştırmanın } \\
\text { sinırlılığ } \\
\text { uygulandığg } \\
\text { saatlerde çalışan }\end{array}$ \\
\hline
\end{tabular}


hastalara ağrısı olduğunda analjezik ile birlikte müzik dinletilmiş, kontrol grubuna standart bakım verilmiştir. Çocukların ağrısı 'Vizüel Analog Skala (VAS)' ile değerlendirilmiş̧tir. göre daha az bulunmuştur.

hemşire sayısının sinırlı olması nedeniyle yeterli örneklem sayısına ulaşılamaması olarak bildirilmiştir.

\section{Tartışma}

Bu sistematik derlemede, beş çalışmada minör ve majör cerrahi operasyon sonrası, okul çağ1 ve adölesan grubu çocuklara nonfarmakolojik yöntem olarak müzik terapi kullanıldığı ve çocukların hissettiği ağrıyı anlamlı olarak azalttığı görülmüştür. Müzik terapi olarak canlı ve kayıtlı müzik terapi yöntemi kullanılmıştır. Müzik dinletisi, Calcaterra ve ark.'nın (2014) yapmış olduğu çalışmada günü birlik cerrahi servisinde, Suresh ve De Oliveira'nın (2015) çalışmasında ortopedi, nöroşirürji, üroloji, plastik cerrahi ve genel cerrahi servislerinde, Sayar ve Ergin'in (2014) çalışmasında, ortopedi ve travmatoloji servisinde, Nelson ve ark.'nın (2016) yapmış olduğu çalışmada, beyin ve sinir cerrahisi servisinde, Nilsson ve ark.'nın (2009) yaptı̆̆ çalışmada ise günü birlik cerrahi servisinde yatan çocuklara cerrahi operasyon öncesi ve/veya operasyon sonrası dinletilmiştir (23,24,25,26,28). Suresh ve De Oliveira (2015), Sayar ve Ergin'in (2014), Nelson ve ark.'nın (2016) yapmış olduğu çalışmada, kontrol grubu ile karşılaştırıldığında, deney grubunda olan çocukların ağrı skorlarının anlamlı derecede azaldığı görülmüştür $(24,25,28)$. Nilsson ve ark.'nın (2009) ve Calcaterra ve ark.'nın (2014) yapmış olduğu çalışmada müzik terapinin ağrı skorlarına anlamlı bir etkisi olmadığı saptanmıştır $(23,26)$.

Okul çağı çocukları için ameliyat sonrası ağrı, kognitif ve duygusal olarak çok büyük bir endişe ve korkuya neden olur. $\mathrm{Bu}$ yaş grubunda ameliyat sonrası ağrının tedavisinde kullanılan en yaygın yol ilaç tedavisidir (22). Bu sistematik derlemede incelenen ve okul çağı çocukları ile çalışılan iki araştırmada müziğin ameliyat sonrası ağrıya etkisi incelenmiştir $(25,26)$. Sayar ve Ergin'in (2014) yaptığı çalışmada okul çağı çocuklarına, post-operatif dönemde ağrısı olduğunda analjezik ile birlikte müzik dinletilmiştir (25). Calcaterra ve ark.'nın (2014) yapmış olduğu çalışmada ise, cerrahi operasyon geçiren çocuklara ayılma ünitesinde 20'şer dakika klasik müzik dinletilmiştir. Her iki çalışmada da kontrol grupları standart bakım almıştır. Çalışmaların sonucunda, Sayar ve Ergin'in (2014) yaptığı çalışmada post-operatif dönemde müzik dinletilen okul çağı çocuklarının ağrı puanlarının istatistiksel olarak daha düşük olduğu saptanırken, Calcaterra ve ark.'nın (2014) yapmış olduğu çalışmada ağrı puanları açısından iki grup arasında anlamlı bir farklılık bulunmamıştır $(25,26)$.

Adölesan grubu çocuklar fiziksel ve mental ağrının karmaşık nedenlerini anlayabilirler. Doğru iletişim teknikleriyle tedavi ve bakımda rol alıp, iş birliği içerisinde olabilirler. Ayrıca adölesanların ağrıya karşı kontrollü davranış tepkileri vardır (22). Ancak ilgili literatür incelendiğinde, adölesanlar ile cerrahi sonrası non-farmakolojik ağrı giderme yöntemleri kullanılarak yapılan çalışmaların çok az olduğu görülmüştür. Bu sistematik derlemede iki çalışma $(23,24)$ hem okul çağı çocukları hem de adölesan grubu çocuklar ve bir çalışma da (28) sadece adölesan grubu çocuklar ile yapılmıştır. Nilsson ve ark.'nın (2009) yaptığı çalışmada, adölesanların post-operatif dönemde ağrı puanları müzik ve kontrol grubu olmak üzere iki grup da karşılaştırılmıştır. Minör cerrahi sonrası müzik gurubunda morfin ihtiyacının anlamlı derecede azaldığı fakat müziğin anksiyete ve ağrı üzerinde etkisi olmadığı; aynı çalışmada çocukların müziği sakinleştirici ve rahatlatıcı olarak değerlendirdiği belirtilmiştir (23). Suresh ve De Oliveira tarafından yapılan çalışma major cerrahi operasyon geçiren okul çağı çocukları ve adölesanlar ile yapılmıştır. Çalışmaya katılan çocuklar sesli kitap, müzik ve sessizlik olarak üç gruba (n=19) ayrılmıştır. Postoperatif dönemde ağrı skorlarının hem müzik grubunda hem de sesli kitap grubunda azaldığı bulunmuştur (24). Nelson ve ark.'nın yapmış olduğu çalışmada ise bir gruba cerrahi operasyon öncesi müzik terapi hakkında eğitim verilmiş ve postoperatif dönemde müzik terapi uygulanmış ve bir gruba da cerrahi operasyon öncesi müzik terapi hakkında eğitim verilmeden post-operatif dönemde müzik terapi uygulanmıştır. İki grupta da ağrı ve anksiyete puanlarında anlamlı düzeyde azalma olduğu görülmüştür (28).

Türkiye'de, çocuk hastalarda ameliyat sonrası ağrı üzerinde müziğin etkisini inceleyen yalnızca bir çalışmaya ulaşılmıştır. Araştırma yarı deneysel tipte tasarlanmış, bir üniversite hastanesinin ortopedi ve travmatoloji servisinde yatan, okul çağı çocuklarla yapılmıştır. Müzik terapinin ameliyat sonrası ilk altı saatte ağrı gidermede olumlu etkisi olduğu saptanmıştır (25). Sayar ve Ergin'in (2014) yaptı̆̆ı çalışmada cerrahi operasyon erken dönemde, ağrı şiddetinin azaltılması için müziğin farmakolojik yöntemlerle beraber kullanılması ve hemşirelerin müzik terapi gibi non-farmakolojik yöntemleri kullanmalarının sağlanması ve çok merkezli kanıta dayalı çalışmalar yapılmasının önemi vurgulanmıştır (25).

Cerrahi operasyon çocuklar için en stresli olaylardan biridir ve operasyon sonrası oluşan stres hipotalamik-hipofiz adrenal (HPA) bezini uyararak, kortizol salınımına neden olur. Uzun süre kortizol salınımı, kardiyovasküler bulguların (kalp atımında artış, vazokonstrüksiyon, hipertansiyon) oluşmasına zemin hazırlar (29-31). Müzik terapisi psikolojik ve duygusal olarak ayrıca nörolojik, endokrinolojik ve kardiyovasküler sistemde olumlu değişikliklere sebep olur. Dikkati dağıtarak, rahatlamayı sağlar ve stres hormonlarının salınımını azaltır (22,27). Bu sistematik derlemede, Calcaterra ve ark.'nın yapmış olduğu çalışmada, operasyon sonrası çocuklara klasik müzik dinletilerek, kontrol grubunun ve araştırma grubunun ağrı puanları, kalp atım hızları, kan basınçları, oksijen satürasyonları, glukoz ve kortizol düzeyleri karşılaştırılmıştır (26). Yapılan istatiksel analizler sonucunda araştırma grubunda, kan basıncının ve kan glukoz değerinin daha düşük olduğu bulunmuş, ağrı puanları, kalp atım hızı ve serum kortizol düzeyleri açısından ise gruplar arasında anlamlı farklılık bulunmamıştır (26). 
Objektif ağrı ölçümünde kullanılan kesin bir ölçüm aracı yoktur. Çoğunlukla "VAS (Görsel Analog Skala)", "FAS (Yüz Afektif Skala)”, "FLACC kısaltılması Yüz (Face), Bacak (Leg), Aktivite (Activity), Ağlama (Cry), Teselli Edilirlik (Consolability)", kelimelerin baş harflerinden oluşan ölçüm araçları kullanılmaktadır (22).

Bu sistematik derlemeye dahil edilen çalışmalarda; cerrahi operasyon öncesi ve sonrası 20'şer 30'ar 45'er dakika olmak üzere müzik terapisi çocuklara uygulanmıştır. Müzik terapisinin post-operatif dönemde ağrıya olan etkisini değerlendirmek için 'Coloured Analogue Scale' (23), 'Face, Legs, Activity, Cry, Consolabity (FLACC) Pain Scale’ (26), 'The Faces Pain Scale' (24), 'Numeric Rating Scale (NRS) (28), 'Vizüel Analog Skala (VAS) (25) ölçüm araçları kullanılmıştır. Suresh ve De Oliveira (2015), Nelson ve ark.’nın (2016) ve Sayar ve Ergin'in (2014) yapmış olduğu çalışmada bu ölçüm araçlarının puan ortalamalarına göre; deney grubunda yer alan çocukların ağrı puanları kontrol grubundaki çocuklara göre daha düşük bulunmuştur. Nilsson ve ark.'nın (2009) ve Calcaterra ve ark.'nın (2014) yapmış olduğu çalışmada ise kontrol ve deney grubunda yer alan çocukların ağrı puanlarında anlamlı bir farklılık saptanmamıştır. Bu çalışmalarda anlamlı bir farklılık saptanmamasına rağmen, deney grubunda yer alan çocukların post operatif dönemde morfin ihtiyacının anlamlı derecede azaldığı (23) ve kan basıncının ve kan glukoz değerinin daha düşük olduğu saptanmıştır (26). Nilsson ve ark.'nın (2009) yapmış olduğu çalışmada post- operatif dönemde çift kör çalışma dizaynının kullanılmaması ve bazı metodolojik faktörlerin araştırma sınırlılığı olarak belirtilmiştir.

\section{Sonuçların Uygulamada Kullanımı}

Bu sistematik derlemeye dahil edilen çalışmalarda, kayıtlı ve canlı müzik terapi yönteminin 3-19 yaş grubu çocuklarda cerrahi girişim sonrası non-farmakolojik yöntem olarak kullanılmıştır. Yapılan analizlerde, üç çalışmada post operatif dönemde müziğin ağrıyı azalttığı görülürken $(24,25,28)$ iki çalışmada müzik terapinin ağrı üzerine etkisi saptanmamıştır $(23,26)$. Sonuç olarak, müziğin cerrahi işlem geçiren çocuklarda ameliyat sonrası ağrının azaltılmasında anlamlı bir etkiye sahip olabileceğ çalışmalarla kanıtlanmıştır. Bu çalışmadan elde edilen sonuçlar, müzik terapinin çocukların ağrısının giderilmesinde klinik kullanım için düşünebileceğini göstermektedir.

Bu sonuçlar doğrultusunda;

- Çocuklarda cerrahi sonrası ağrıyı gidermek için müzik terapi yönteminin non-farmakolojik bir hemşirelik girişimi olarak kullanılmasının yaygınlaştırılması ve bu amaçla eğitimlerin yapılması,

- $\quad$ Ülkemizde çocuk hastalarda ameliyat sonrası ağrı üzerinde müziğin etkisini inceleyen daha kapsamlı ve daha geniş örneklemlerle çalışmaların yapılması önerilmektedir.

\section{Bilgilendirme}

Bu çalışmada yazarların katkı beyanı şöyledir; fikir/kavram MG; tasarım MG, DY; denetleme/danışmanlık FY, SŞ, HBY; veri toplama ve işleme MG, DY; analiz / yorum MG, DY, RK; kaynak taraması: MG, DY, RK; makalenin yazımı MG, DY, RK; eleştirel düşünme FY, SŞ, HBY.

Araştırma ile ilgili herhangi bir projeden ya da firmadan destek alınmamıştır. Araştırmanın bütçesi araştırmacılar tarafından karşılanmıştır. Yazarlar arasında herhangi bir çıkar çatışması yoktur. Ayrıca sorumlu olduğumuz araştırmada herhangi bir firma ya da kurum ile çıkar ilişkisi bulunmamaktadır.

\section{Kaynaklar}

1. International Association for the Study of Pain. IASP Terminology Pain Terms [Internet]. 2011 [cited 2020 Jun 15$].$ Available from: https://www.iasp-pain.org/Education/Content.aspx?ItemNumber=2051

2. Giordano F, Zanchi B, De Leonardis F, Rutigliano C, Esposito F, Brienza N, et al. The influence of music therapy on preoperative anxiety in pediatric oncology patients undergoing invasive procedures. Arts Psychother. 2020;68(March).

3. Millett CR, Gooding LF. Comparing Active and Passive Distraction-Based Music Therapy Interventions on Preoperative Anxiety in Pediatric Patients and Their Caregivers. J Music Ther. 2017;54(4):460-78.

4. Apfelbaum JL, Chen C, Mehta SS, Gan and TJ. Postoperative Pain Experience: Results from a National Survey Suggest Postoperative Pain Continues to Be Undermanaged. Anesth Analg. 2003;97(2):534-40.

5. Crowe L, Chang A, Fraser JA, Gaskill D, Nash R, Wallace K. Systematic review of the effectiveness of nursing interventions in reducing or relieving post-operative pain. JBI Database Syst Rev Implement Reports. 2008;6(4):165224.

6. Astuto Marinella, Rosano G, Rizzo G, Disma Nicola. Methodologies for the treatment of acute and chronic nononcologic pain in children. Minerva Anestesiol. 2007;73(9):459-65.

7. NS M. Management of Postoperative Pain in Children. Arch Dis Child Educ Pract Ed. 2007;92(1).

8. Van der Heijden MJE, Jeekel J, Rode H, Cox S, van Rosmalen J, Hunink MGM, et al. Can live music therapy reduce distress and pain in children with burns after wound care procedures? A randomized controlled trial. Burns. 2018 Jun 1;44(4):823-33.

9. Segerdahl M, Warren-Stomberg M, Rawal N, Brattwall M, Jakobsson J. Children in day surgery: clinical practice and routines. The results from a nation-wide survey. Acta Anaesthesiol Scand. 2008 May 21;52(6):821-8.

10. Taylor EM, Boyer K, Campbell FA. Pain in hospitalized children: A prospective cross-sectional survey of pain prevalence, intensity, assessment and management in a Canadian pediatric teaching hospital. Acute Pain. 2008 Jun;10(2):107-8.

11. Lee JY, Jo YY. Attention to postoperative pain control in children. Korean J Anesthesiol. 2014;66(3):183. 
12. Anand KJS. Pain, plasticity, and premature birth: A prescription for permanent suffering? Nat Med. 2000;6(9):971-3.

13. Weisman S, Bernstein B, Schechter N. Consequences of Inadequate Analgesia During Painful Procedures in Children. Arch Pediatr Adolesc Med. 1998;152(2).

14. Miladinia M, Baraz S, Zarea K. Controlling Acute Post-operative Pain in Iranian Children with using of Music Therapy. Int J Pediatr. 2016 May 1;4(5):1725-30.

15. Chou R, Gordon DB, de Leon-Casasola OA, Rosenberg JM, Bickler S, Brennan T, et al. Management of Postoperative Pain: A Clinical Practice Guideline From the American Pain Society, the American Society of Regional Anesthesia and Pain Medicine, and the American Society of Anesthesiologists' Committee on Regional Anesthesia, Executive Commi. J Pain. 2016;17(2):131-57.

16. Sng QW, He H-G, Wang W, Taylor B, Chow A, Klainin-Yobas P, et al. A Meta-Synthesis of Children’s Experiences of Postoperative Pain Management. Worldviews Evidence-Based Nurs. 2017;14(1):46-54.

17. Howard R, Carter B, Curry J, Morton N, Rivett K, Rose M, et al. Good Practice in Postoperative and Procedural Pain Management. Background. Paediatr Anaesth. 2008;18(1).

18. Standley JM, Gutierrez C. Benefits of a Comprehensive Evidence- Based NICU-MT Program : Family- Therapy for Premature Infants. Pediatr Nurs. 2020;46(1):40-6.

19. Thanh Nhan Nguyen, Nilsson S, Hellström A-L, Bengtson A. Music Therapy to Reduce Pain and Anxiety in Children With Cancer Undergoing Lumbar Puncture: A Randomized Clinical Trial. J Pediatr Oncol Nurs. 2010;27(3):146-55.

20. Noguchi LK. The Effect of Music Versus Nonmusic on Behavioral Signs of Distress and Self-Report of Pain in Pediatric Injection Patients. J Music Ther. 2006;43(1):16-38.

21. Poulsen MJ, Coto J. Nursing Music Protocol and Postoperative Pain. Pain Manag Nurs. 2018;19(2):172-6.

22. Büyükgönenç L, Törüner EK. Çocuk Yaşlarında Ağrı ve Hemşirelik Yönetimi. In: Conk Z, Başbakkal Z, Yilmaz HB, Bolışık B, editors. Pediatri Hemşireliği. 2nd ed. Ankara: Akademisyen Kitabevi A.Ş.; 2018. p. 881-96.

23. Nilsson S, Konkinsky E, Nilsson U, Sidenvall B. School-aged children's experiences of postoperative music medicine on pain, distress, and anxiety. Pediatr Anesth. 2009;19(12):1184-90.

24. Sunitha Suresh BS, De Oliveira GS, Suresh S. The effect of audio therapy to treat postoperative pain in children undergoing major surgery: a randomized controlled trial. Pediatr Surg Int. 2015;31(2):197-201.

25. Sayar Serap, Ergin Dilek. Ortopedi Servisinde Yatan Çocuk Hastalarda Ameliyat Sonrası Ağrı Yönetiminde Müziğin Etkisinin İncelenmesi. Dokuz Eylül Üniversitesi Hemşirelik Fakültesi Elektron Derg. 2019;12(1).

26. Calcaterra V, Ostuni S, Bonomelli I, Mencherini S, Brunero M, Zambaiti E, et al. Music benefits on postoperative distress and pain in pediatric day care surgery. Pediatr Rep. 2014;6(3).

27. Ullsten A, Eriksson M, Klässbo M, Volgsten U. Live music therapy with lullaby singing as affective support during painful procedures: A case study with microanalysis. Nord J Music Ther. 2017;26(2):142-66.

28. Nelson K, Adamek M, Kleiber C. Relaxation Training and Postoperative Music Therapy for Adolescents Undergoing Spinal Fusion Surgery. Pain Manag Nurs. 2017;18(1):16-23.

29. Baş NG, Karatay G, Bozoğlu Ö, Akay M, Kunduracı E, Aybek H. Hemşirelerin Ameliyat Sonrası Ağrıya İlişkin Uygulamaları. Hacettepe Üniversitesi Hemşirelik Fakültesi Derg. 2016;3(2):40-9.

30. Bernardi L, Porta C, Casucci G, Balsamo R, Bernardi NF, Fogari R, et al. Dynamic Interactions Between Musical, Cardiovascular, and Cerebral Rhythms in Humans. Circulation. 2009;119(25):3171-80.

31. Yinger OS. Music Therapy as Procedural Support for Young Children Undergoing Immunizations: A Randomized Controlled Study. J Music Ther. 2016;53(4):336-63 